\title{
Нематериальное культурное наследие как предмет охраны исторического поселения: размышления о предмете охраны
}

\author{
Э.А.Шевченко, НИИТИАГ, Москва
}

Рассматривается вопрос правомерности и необходимости внедрения понятия «нематериальное культурное наследие» в предмет охраны исторического поселения. Одновременно анализируется правомерность распространения понятия «предмет охраны» на исторические поселения. Анализируется формулировка понятия «нематериальное культурное наследие», принятая на Генеральной конференции ЮНЕСКО в 2003 году (конвенция «0б охране нематериального культурном наследии»). В статье отмечается некоторая некорректность принятого документа. В частности, в Конвенции при перечислении областей, в которых проявляется нематериальное наследие, отсутствует указание на носителей «культурных пространств...», которые приведены в определении понятия «нематериальное культурное наследие». Введённое в качестве одного из показателей нематериального наследия «культурное пространство» применительно к поселению ассоциируется с понятием «предмет охраны», одним из показателей исторического поселения.

Рассматривается само понятие «предмет охраны», позаимствованное у объектов культурного наследия. Отмечается, что споры среди специалистов о понятии «предмет охраны» идут до сих пор, но они не затрагивают предмета охраны исторического поселения. Создаётся впечатление, что к нему (предмету охраны поселения) нет претензий, и это - когда перекладывание критериев с ОКН (объект культурного наследия) на населённый пункт (поселение) категорически неверно и просто неграмотно. Конечно, в видах ОКН присутствует такой крупный территориальный объект как достопримечательное место (далее ДМ), что и позволило законодателю, сделать столь некорректную запись в законодательном акте.

На основании проведённого исследования делается вывод, что нематериальное культурное наследие в историческом поселении должно быть признано предметом его охраны и войти в число других градоформирующих признаков исторического поселения.

Ключевые слова: нематериальное культурное наследие, объекты культурного наследия, исторические города, предмет охраны, градоформирующий фактор и градоформирующий объект.

Intangible Cultural Heritage as a Subject of Protection of the Historical Settlement: Reflections on the Subject of Protection

\section{E.A.Shevchenko, NIITIAG, Moscow}

The question of the legality and the need to introduce the concept of "intangible cultural heritage" in the protection of the historical settlement is being considered. At the same time, the legality of extending the concept of "protection" to historical settlements is being analyzed. The wording of the concept of "intangible cultural heritage" adopted at the UNESCO General Conference in 2003 (Convention on the Protection of Intangible Cultural Heritage) is being analysed. The article notes some incorrectness of the adopted document. In particular, the Convention, when listing areas of intangible heritage, does not refer to the carriers of "cultural spaces..." which are defined in the definition of "intangible cultural heritage". Introduced as an indicator of intangible heritage, the "cultural space" in relation to the settlement is associated with the concept of "protection object", one of the indicators of the historical settlement.

The very concept of "protection" borrowed from cultural heritage sites is considered. It is noted that the debate among experts about the concept of "protection" is still going on. but they do not affect the subject of protection of the historic settlement. It seems that there are no claims to it (the subject of settlement protection) and this is when the transfer of criteria from the OCN (cultural heritage object) to the settlement is categorically wrong and simply illiterate. Of course, in the types of OCN there is such a large territorial object as a landmark place (more DM), which allowed the legislator to make such an incorrect entry into the legislation.

Based on the study, it is concluded that the intangible cultural heritage in the historical settlement should be recognized as the subject of its protection and be among the other city-forming features of the historical settlement.

Keywords: intangible cultural heritage, cultural heritage sites, historical cities, subject of protection, city-forming factor and city-forming object.

...nонятие «предмет охраны», впервые введённое в 2002 г. при принятии Федерального закона № 73-Ф3 «0б объектах культурного наследия (памятниках истории и культуры) народов Российской Федерации», содержит в себе мину замедленного действия. А. Баталов [1]

Подобно мифическому зверю, архитектура возникает из психокультурного ландшафта, сформированного общественными, политическими и экономическими условиями.

С. Джейкоб [2, с. 6] 
0 «рождении» такого «объекта» культурного наследия как «нематериальный» на официальном уровне заговорили в 2003 году после работы Генеральной конференции ЮНЕСКО, на которой была принята конвенция «0б охране нематериального культурного наследия» ${ }^{1}$. В статье 2 Конвенции дается определение:

«1. “Нематериальное культурное наследие” означает обычаи, формы представления и выражения, знания и навыки, - а также связанные с ними инструменты, предметы, артефакты и культурные пространства, - признанные сообществами, группами и, в некоторых случаях, отдельными лицами в качестве части их культурного наследия. Такое нематериальное культурное наследие, передаваемое от поколения к поколению, постоянно воссоздаётся сообществами и группами в зависимости от окружающей их среды, их взаимодействия с природой и их истории и формирует у них чувство самобытности и преемственности, содействуя тем самым уважению культурного разнообразия и творчеству человека.

2. “Нематериальное культурное наследие", как оно определено в пункте 1 выше, проявляется, в частности, в следующих областях:

а) устные традиции и формы выражения, включая язык в качестве носителя нематериального культурного наследия;

b) исполнительские искусства;

c) обычаи, обряды, празднества;

d) знания и обычаи, относящиеся к природе и вселенной;

е) знания и навыки, связанные с традиционными ремёслами».

Однако обращает на себя внимание некоторая некорректность документа. В частности, в п. 2 Конвенции при перечислении областей, в которых проявляется нематериальное наследие, отсутствует указание на носителей «культурных пространств...».

Отсутствие разъяснения, что есть «культурные пространства», позволяет сделать предположение, что это могут быть пространства в городской среде. То есть это открытое пространство свободное от застройки, но сформированное застройкой. Обращаясь к такому градостроительному объекту, как историческое поселение, мы находим, что показателями ценности этого объекта являются объёмно-пространственная структура и соотношение между различными городскими пространствами (свободными, застроенными, озеленёнными). И эти ценностные показатели являются предметом охраны исторического поселения. Но ведь именно эти городские пространства можно охарактеризовать как нематериальное культурное наследие, присущее локальному фрагменту среды в конкретном населённом пункте. То есть конкретная «составляющая предмет охраны» исторического поселения может быть идентифицирована как нематериальное культурное наследие?

Понятие «предмет охраны» появилось применительно к памятникам архитектуры, то есть к объектам недвижимости.
Идея введения в профессиональный оборот столь сложного понятия родилась в начале 90-х годов прошлого века у специалистов Ассоциации исследователей Санкт-Петербурга (руководитель д. арх., академик Т.А. Славина). Ими же было предложено следующее определение: «В государственных списках памятников истории и культуры перечислены объекты охраны. Под предметом охраны подразумеваются те элементы, параметры, характеристики архитектурно-градостроительного объекта, которые, собственно, и являются носителями его историко-культурной ценности. Понятие «предмет охраны» призвано конкретизировать содержание охранной деятельности» [3].

В аспекте деятельности предмет охраны есть предмет регулирования (ограничения) действий всех участников градостроительного процесса, зафиксированный полноценными с юридической точки зрения документами.

В главном документе, регламентирующем охрану историко-культурного наследия России, - Федеральном законе Российской Федерации № 73-Ф3 «0б объектах культурного наследия (памятниках истории и культуры) народов Российской Федерации» до настоящего времени нет чёткой формулировки этого понятия. Только пункте 8 статьи 17 («Документы, представляемые в орган государственной власти для принятия решения о включении объекта культурного наследия в реестр») читаем - «описание особенностей объекта, послуживших основаниями для включения его в реестр и подлежащих обязательному сохранению (далее - предмет охраны)». То есть, особенности объекта недвижимого имущества, каковым является объект культурного наследия (№ 73-Ф3 ст. 3) и есть предмет его охраны. К сожалению, разъяснения того, что считать особенностями объекта культурного наследия, в законодательном акте не дано.

Однако «предмет охраны» всплывает в статье 59 «Понятие исторического поселения» данного законодательного акта, в которой дан перечень предметов охраны исторического поселения, не являющегося объектом культурного наследия:

«2) Предмет охраны исторического поселения включает в себя:

1) исторически ценные градоформирующие объекты здания и сооружения, формирующие историческую застройку и объединённые в том числе масштабом, объёмом, структурой, стилем, конструктивными материалами, цветовым решением и декоративными элементами;

2) планировочную структуру, включая её элементы;

3) объёмно-пространственную структуру;

4) композицию и силуэт застройки - соотношение вертикальных и горизонтальных доминант и акцентов;

5) соотношение между различными городскими пространствами (свободными, застроенными, озеленёнными);

${ }^{1}$ UNESCO Convention on the Protection of Intangible Cultural Heritage Paris, 17 October 2003 (https://www.un.org/ru/documents/decl_conv/conventions/ cultural_heritage_conv.shtml). 
6) композиционно-видовые связи (панорамы), соотношение природного и созданного человеком окружения»².

\section{O предмете охраны исторического поселения и нематериальном наследии}

Понятие «предмет охраны» применительно к историческому поселению было введено в законодательный акт № 73-Ф3 только в 2012 году. Несмотря на то, что в отличие от объекта культурного наследия в историческом поселении перечислены составляющие предмет охраны показатели, по сути понятие остаётся не раскрытым, а все перечисленное - это только «верхний слой», характеризующий ценность некоторой части застройки населённого пункта, атрибутируемой как историческое поселение.

0 неоднозначности введённого законом № 73-Ф3 понятия «предмет охраны» говорил в своё время А.Л. Баталов, приводя ряд аргументов, один из которых указывал, что «это необходимо для страховой оценки и как подготовка к грядущей приватизации, чтобы памятник не стоил столько, сколько стоит земля под ним». Хочу привести еще одно высказывание Андрея Леонидовича, которое очень важно для анализа понятия «предмет охраны» применительно к «историческому поселению» - «Понятие "предмет охраны" также является ключевым при определении границ допустимого вмешательства при ремонте и приспособлении памятника к современному использованию. В обоих случаях работы на памятнике допускаются "без изменения его особенностей, составляющих предмет охраны". Тем же условием определяется и право пользования памятником для юридических и физических лиц. Содержанием предмета охраны определяются те обязанности, которые государство налагает на арендатора или собственника. Таким образом, именно содержание предмета охраны в каждом конкретном случае служит гарантией сохранения памятника» [1].

Споры среди специалистов об этом предмете идут до сих пор, то затухая, то воспламеняясь с новой силой, но они (споры) не касаются предмета охраны исторического поселения. Создаётся впечатление, что к нему (предмету охраны ИП) нет претензий, и это - когда перекладывание критериев с ОКН (объект культурного наследия) на населённый пункт (поселение) категорически неверно, просто неграмотно. Конечно, в видах ОКН присутствует такой крупный территориальный объект, как достопримечательное место (далее ДМ), что и позволило законодателю внести столь некорректную запись в законодательный акт. То есть законодатель этим создал внутреннюю коллизию в самом законе, уровняв, по сути, два понятия: «достопримечательные места» и «исторические поселения», не понимая глубокой сущностной разницы между ними. Только этим можно объяснить раздел 4.3. «Достопримечательные места, исторические поселения» в «Методических указаниях по определению предмета охраны для объектов, предложенных к включению в реестр объектов культурного наследия, выявленных объектов культурного наследия и объектов культурного наследия федерального и регионального значения (памятников истории и культуры», разработанные по заданию Комитета по культурному наследию города Москвы (Москомнаследие) в 2011 году ${ }^{3}$.

В 2013 году Минкультом России был принят приказ от 13 января 2016 г. № 28 «0б утверждении Порядка определения предмета охраны объекта культурного наследия, включённого в единый государственный реестр объектов культурного наследия (памятников истории и культуры) народов Российской Федерации в соответствии со статьёй 64 Федерального закона от 25 июня 2002 г. № 73-Ф3 “0б объектах культурного наследия (памятниках истории и культуры) народов Российской Федерации"». Приказ был зарегистрирован в Минюсте России 2 августа 2016 г. (рег. № 43060), но в электронной версии приказа сообщается, что он (приказ) не вступил в силу. Тем не менее содержание утверждённого «Порядка» представляет значительный интерес для аналитического исследования. Так, в нём не упоминается о наличии вышеупомянутых Методических рекомендаций. Более того, в п. 3 Приложения к Приказу сказано: «Разработка проекта предмета охраны объекта культурного наследия осуществляется на основании историко-архитектурных, историко-градостроительных, архивных, археологических, натурных и иных исследований (далее - историко-культурные исследования)»4. Это практически выводит «Методические указания» из правового поля. Можно сказать, что это недопустимая «оплошность» Минкульта России, так как именно в этих указаниях появился раздел 5.1. «Нематериальные и материальные особенности объекта культурного наследия. Методы формализации ценностных характеристик», представляющий наиболее ценную часть Указаний.

Авторы Указаний впервые показали истинную необходимость сохранения историко-культурного наследия, подчеркнув, что «каждый объект культурного наследия определяется набором материальных и нематериальных особенностей». В

\footnotetext{
2 Федеральный закон от 25.06.2002 № 73-Ф3 (ред. от 30.04.2021) «0б объектах культурного наследия (памятниках истории и культуры) народов Российской Федерации» (https://legalacts.ru/doc/federalnyi-zakon-ot-25062002-n-73-fz-ob/).

${ }^{3}$ Книга 2. «Методические указания по определению предмета охраны для объектов, предложенных к включению в реестр объектов культурного наследия, выявленных объектов культурного наследия и объектов культурного наследия федерального и регионального значения(памятников истории и культуры)» (http://pf-grado.ru/wp-content/uploads/2017/01/Kniga-2.-Metodicheskie-ukazaniya-po-opredeleniyu-predmeta-ohranyi.pdf).

${ }^{4}$ Приказ Министерства культуры РФ от 13 января 2016 г. № 28 «0б утверждении Порядка определения предмета охраны объекта культурного наследия, включённого в единый государственный реестр объектов культурного наследия (памятников истории и культуры) народов Российской Федерации в соответствии со статьёй 64 Федерального закона от 25 июня 2002 г. № 73-Ф3 “0б объектах культурного наследия (памятниках истории и культуры) народов Российской Федерации"» (https://www.garant.ru/products/ipo/prime/doc/71357670/).
} 
Указаниях приведены основные (элементарные, по мнению авторов) нематериальные особенности. Это датировка, историческая (мемориальная) ценность, историко-художественная ценность, технологическая ценность, редкость, авторство, историческая функция, градостроительная, ансамблевая ценность ${ }^{5}$. Но все указанные нематериальные особенности применены исключительно к памятникам и ансамблям. Даже ДМ, хотя и признано объектом культурного наследия, не указано как объект, обладающий нематериальным наследием.

В данной статье рассматривается нематериальное наследие как один их показателей ценностных характеристик градостроительного объекта культурного наследия, каковым является «историческое поселение». Анализ формулировок нематериальных показателей ОКН, приведённых в «Указаниях» свидетельствует, что практически все они применимы к историческому поселению. Однако вряд ли все перечисленные показатели можно отнести исключительно к нематериальным ценностям. Ведь нематериальные ценности позволяют говорить о присутствии «духа места», как о некоем «духовном элементе, придающим территории её индивидуальный характер, смысл и эмоциональность» ${ }^{6}$. Таким образом, мы говорим о показателе уникальной ценности градостроительного объекта - его «Душе». Именно изучение «души» города, позволяет постичь его истинную ценность, величие и значимость для всех живущих и всех ушедших поколений, вложивших свои душевные качества, любовь, умение в создание и развитие любого поселения. Поэтому, по мнению Н.П. Анциферова, город является «сгустком культуры», зафиксированной в материальных объектах и сформированной пространственной среде поселения [4].

На практике нематериальное наследие поглощено понятием «градоформирующие факторы», зафиксированном в Федеральном законе № 73-Ф3 как «градоформирующие объекты».

\section{Что считать исторически ценными градоформирующими объектами}

Следует уточнить, что с момента первого появления понятие «градоформирующие объекты» притерпело изменения, что отражено в Законе № 73-ФЗ, где оно заменено на «градоформирующие факторы». Следует сопоставить эти словосочетания. Впервые словосочетание «градоформирующие объекты» было применено к неким объектам, обладающим признаками историко-культурной ценности, в 1988 году при разработке «Методических указаний об использовании памятников истории и культуры как градоформирующих факторов при разработке генеральных планов и проектов детальной планировки городов».

Актуальность этих Методических указаний вытекала из проблем градостроительства, возникших на том этапе. Проблемы заключались в повышении качества и разнообразия застройки городов. При этом, как сказано в предисловии «к Методическим указаниям, снятие этих проблем «...имеет не только архитектурно-градостроительное, художественно-эстетическое, но и социально-политическое значение, способствует формированию чувства патриотизма, любви к своему городу, гармоничному развитию личности советского человека» ${ }^{7}$.

Именно в предисловии авторы Методических указаний раскрыли содержание вводимого понятия. Градоформирующим фактором, определяющим направленность преобразования и развития городов, при которых обеспечивалось бы сохранение и преемственное развитие своеобразных черт архитектурного облика, функциональной организации и планировочной структуры городов, приёмов их планировки и застройки, является ценное историко-культурное наследие, включающее памятники, все ценные элементы исторической среды, традиционные и свойственные конкретному городу архитектурно-градостроительные особенности. Совершенно очевидно, что речь идёт о материальной составляющей фактора. Но именно так была поставлена задача разработчикам Методических указаний, которая была решена блестяще.

Методические указания должны были решить проблемы, возникающие при реконструкции и развитии городов, путём всестороннего и активного использования материальных памятников истории и культуры, ценных элементов исторической среды, различных качеств и взаимосвязей, архитектурно-градостроительных традиций. Именно с этой целью было введено понятие «градоформирующие факторы», то есть факторы, учёт которых способен повлиять на снятие проблем взаимосочетания нового и старого в застройке городов.

В принятом в 2002 году законе 73-Ф3, понятие «фактор» заменено на понятие «объект». Однако получена не равнозначная замена (подмена).

Может ли словосочетание «градоформирующие факторы» рассматриваться в качестве синонима словосочетания «градоформирующие объекты»? Объединяет эти два понятия слово «градоформирующий», но определяющими суть понятия следует признать слова «фактор» и «объект».

Рассмотрим определение понятий:

«фа́ктор (лат. factor - делающий, производящий) - причина, движущая сила какого-либо процесса, определяющая

\footnotetext{
${ }^{5}$ Книга 2. «Методические указания по определению предмета охраны для объектов, предложенных к включению в реестр объектов культурного наследия, выявленных объектов культурного наследия и объектов культурного наследия федерального и регионального значения(памятников истории и культуры)» (http://pf-grado.ru/wp-content/uploads/2017/01/Kniga-2.-Metodicheskie-ukazaniya-po-opredeleniyu-predmeta-ohranyi.pdf).

${ }^{6}$ ГОСТ Р 59124-2020. Национальный стандарт Российской Федерации. Сохранение объектов культурного наследия. Состав и содержание научно-проектной документации проекта зон охраны. Общие требования; п. 3.49.

${ }^{7}$ «Методические указания об использовании памятников истории и культуры как градоформирующих факторов при разработке генеральных планов и проектов детальной планировки городов» (ЦНИИП градостроительства Госкомархитектуры. - М. : Стройиздат, 1988. - 32 с. - С. 3 ).
} 
его характер или отдельные его черты»․ Следует заметить, что движущая сила процесса может быть нематериальной знание, навык, эмоции могут быть движущей силой и следовательно, этим закладывается нематериальная составляющая результата процесса. То есть фактор обуславливает появление будущего объекта, он формирует его «душу»;

«0бъект (от лат. objectum - предмет) - в самом широком смысле то, на что направлено индивидуальное или коллективное сознание. Когнитивным, или эпистемологическим объектом является всё, что воспринимается, воображается, представляется или мыслится. Объект может быть реальным, вымышленным или даже галлюцинаторным. После И. Канта объектом часто называют то, что противостоит субъекту, его сознанию как часть внешнего мира, т.е. реальный объект» ${ }^{9}$. Но воображаемый объект, как результат мыслительного процесса, тоже нематериален. Приписывать материальному объекту качества нематериального нельзя, но когда материальными объектами сформировано свободное, не застроенное пространство, как например, площадь, и если она (площадь) существует на протяжении всего периода существования поселения, то это пространство может быть признано нематериальным культурным наследием.

Но воображаемый объект, как результат мыслительного процесса, тоже нематериален. Приписывать материальному объекту качества нематериального нельзя, но когда материальными объектами сформировано свободное, не застроенное пространство, как например, площадь, и если она (площадь) существует на протяжении всего периода существования поселения, то это пространство может быть признано нематериальным культурным наследием.

Таким образом, в законе № 73-ФЗ законодатель идентифицировал основу, или движущую силу процесса, с воспринимаемым предметом, реальным (материальный объект недвижимого имущества) или воображаемым (нематериальный объект), заменив «фактор» на «объект». Понятие было интегрировано в статью 59 указанного закона, раскрывающую предмет охраны исторического поселения - «исторически ценные градоформирующие объекты - здания и сооружения, формирующие историческую застройку и объединённые в том числе масштабом, объёмом, структурой, стилем, конструктивными материалами, цветовым решением и декоративными элементами».

В 2006 году Постановлением Правительства Москвы от 18 июля 2006 года № 510-ПП было утверждено положение («0б утверждении положений о Городском реестре недвижимого культурного наследия и об Историко-культурном опорном плане города Москвы»), в котором дана развёрнутая формулировка понятия «исторически ценный градоформирующий объект».
В соответствии с этим Положением: «исторически ценный градоформирующий объект - планировка, застройка, композиция, природный ландшафт, археологический слой, соотношения между различными городскими пространствами (свободными, застроенными, озеленёнными), объемно-пространственная структура, фрагментарное и руинированное градостроительное наследие, форма и облик зданий и сооружений, объединённых масштабом, объёмом, структурой, стилем, материалами, цветом и декоративными элементами, соотношение с природным и созданным человеком окружением, различные функции исторического поселения, приобретенные им в процессе развития, а также другие ценные объекты, подлежащие государственной охране в соответствии с законодательством о культурном наследии» (п. 2.1.19).

Очень сжатая формулировка предложена принятым в 2016 году нормативным документом - ГОСТ Р 56891.4-2016. «Термины и определения. Часть 4. Исторические территории и историко-культурные ландшафты» (п. 3.1.6.) - «Исторически ценные градоформирующие объекты: здания и сооружения, подлежащие сохранению и формирующие историческую композиционно-планировочную структуру и застройку, их масштабные, силуэтные, объёмно-пространственные, планировочные и стилистические характеристики, конструкция, материал и цветовое решение».

Формулировки практически идентичны и понятно, что как в постановлении Москвы, так и в ГОСТе была использована формулировка, зафиксированная в Федеральном законе 2002 года.

Однако эти формулировки серьёзно отличаются от чёткой, выверенной формулировки, приведённой в Методических указаниях 1988 года: «...ценное историко-культурное наследие, включающее памятники, все ценные элементы исторической среды, традиционные и свойственные конкретному городу архитектурно-градостроительные особенности». Сомнительным является только одно - соотнесение перечисленных характеристик с понятием «фактор». Все перечисленные характеристики более соответствуют понятию «объект».

В 2013 году Межпарламентская ассамблея государств участников Содружества Независимых Государств приняла модельный закон «0б охране нематериального культурного наследия» ${ }^{10}$, в котором есть следующие определения:

«Нематериальное культурное наследие - совокупность присущих этнической, социальной или конфессиональной группе духовных, интеллектуальных и нравственно-этических ценностей, являющихся отражением культурной и национальной самобытности общества и охватывающих образ жизни, традиции и формы их выражения, включая язык, нормы и правила поведения, верования, обряды, обычаи, празднества, фольклор, технологии изготовления предметов

${ }^{8}$ https://ru.wikipedia.org/wiki/Фактор.

${ }^{9}$ https://dic.academic.ru/dic.nsf/enc_philosophy/852/\%D0\%9E\%D0\%91\%D0\%AA\%D0\%95\%D0\%9A\%D0\%A2

10 Приложение к постановлению МПА СНГ от 29.11.2013 г.. № 39-17 Межпарламентская Ассамблея государств - участников Содружества Независимых Государств Модельный закон «0б охране нематериального культурного наследия» (https://iacis.ru/public/upload/files/1/535.pdf). 
народного декоративно-прикладного искусства, музыкальных инструментов, предметов быта и народные художественные каноны, реализующиеся в исторически сложившихся сюжетах и образах и стилистике их воплощения;

Объектами нематериального культурного наследия являются: 1) язык, народные знания, верования, празднества, обряды и обычаи, навыки и умения в области исполнительского и декоративно-прикладного народного искусства, фольклор, хранителями и носителями которых являются физические лица, передающие их устным путём из поколения в поколение; 2) язык, народные знания, верования, обряды, обычаи, празднества, произведения фольклора, зафиксированные на разных видах материальных носителей и хранящиеся в государственных музеях, архивах и библиотеках, а также в архивах научно-исследовательских учреждений, учебных заведений, иных организаций;

Носитель нематериального культурного наследия физическое лицо (группа физических лиц), обладающее уникальными знаниями, верованиями, умениями и навыками в области традиционной народной культуры: языка, фольклора, обрядов, обычаев, художественных промыслов и ремёсел, исполнительского и декоративно-прикладного искусства».

Применительно к поселению носителем нематериального наследия тоже являются физические лица, обладающие уникальными знаниями, навыками, умениями, а объектами нематериального культурного наследия являются различные пространства в структуре поселения, зафиксированные и материализованные обычаи, празднества, память о событиях и др.

Ведь любая городская площадь или иное городское пространство - это результат обычаев проводить сходы, собираться на праздничные мероприятия или проводить ярмарки. Площадь перед религиозными объектами - следствие отправления культовых обрядов. Городской сад хранит память всех горожан, участвовавших когда-то в его создании. Таких нематериальных особенностей в каждом поселении довольно много, и они требуют описания и фиксации.

Так, например, небольшая площадь перед Свято-Никольским Черноостровским монастырем в городе Малоярославце хранит память о трагических временах нашего Отечества, о полном разорении города и монастыря в Смутное время, о тяжёлом периоде восстановления, об осаде и уничтожении Малоярославца французскими войсками и немеркнущей победе над ними, о славе наших предков. Духом побед дышит маленькая историческая площадь перед монастырём, представляя собой неувядающее нематериальное наследие народа (рис. 1-3).

В основе самого названия монастыря, по одной из версий, лежит название места, где он воздвигнут, - на вершине Особной горы, называвшейся Черным Острогом. Именно здесь располагается одна из достопримечательностей Малоярославца - древнее городище и, по всей вероятности, название острог - это дань памяти о существовавшем здесь в VIII-XII веках либо жилом, либо стоялом Остроге. Таким образом, можно утверждать, что пространство предмонастырской площади является нематериальным культурным наследием.

Сам монастырь хранит память о купце Целибееве, вложившим огромные деньги в восстановление монастыря, строительство трапезной палаты и настоятельского корпуса (ныне - одно из зданий келий).

Здесь проявляются практически все показатели нематериального наследия - установленная дата основания города и монастыря»; историческая (мемориальная) ценность города и монастыря - документированная, широко известная, легендарная связь объекта с историческими событиями и личностями; историко-художественная ценность - место монастырского комплекса в истории архитектуры; историческая функция - первоначальное и исторически значимое функциональное назначения как города, так и монастыря объекта культурного наследия.

И народ помнит и чтит память о тех временах (рис. 3). Так с 1987 года, ежегодно, на базе военно-исторического музея Малоярославца устраивается реконструкция, того значимого в истории России, сражения. Это праздник, «День Малоярославецкого сражения», который проводится в третье воскресенье октября. Начинаются праздничные мероприятия со службы в знаковом месте города и России, в Никольском соборе Черноостровского монастыря и затем все участники двигаются по улицам города к месту реконструкции, к Ивановскому лугу.

Таким образом, можно утверждать, что нематериальное культурное наследие в историческом поселении должно быть признано предметом его охраны и войти в число других градоформирующих признаков исторического поселения.

\section{Выводы}

Градоформирующие объекты - ценное историко-культурное материальное наследие, включающее исторические здания и сооружения, выявленные объекты культурного наследия, все ценные элементы исторической среды, традиционные и свойственные конкретному городу архитектурноградостроительные особенности (объекты, акцентирующие планировочные решения, создающие объёмно-пространственные доминанты вертикальные и горизонтальные).

Следует воспользоваться предложенным в Методических указаниях 1988 года «Перечнем объектов историко-культурного наследия, обладающих градоформирующими качествами» (Приложение 1 к Методическим указаниям), приведя их в соответствие с требованиями Федерального закона № 73-Ф3:

1) выявленные объекты культурного наследия - здания и сооружения, комплексы;

2) достопримечательные места - объекты градостроительного искусства (историческиецентры, кварталы, площади,улицы);

3) памятники истории - здания и сооружения. Памятные места, имеющие историко-мемориальную ценность и достоверность;

4) рядовая застройка (массивы или фрагменты), формирующая облик целостных участков городской среды, окружа- 


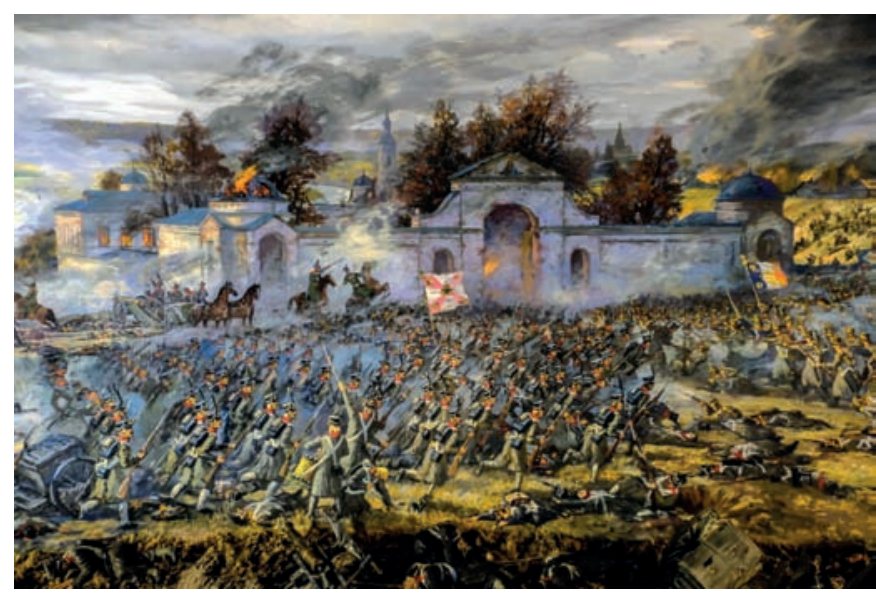

Рис. 1. Диорама «Сражение при Малоярославце 12 [24] октября 1812 года». Фрагмент (из открытого доступа сети Интернет)

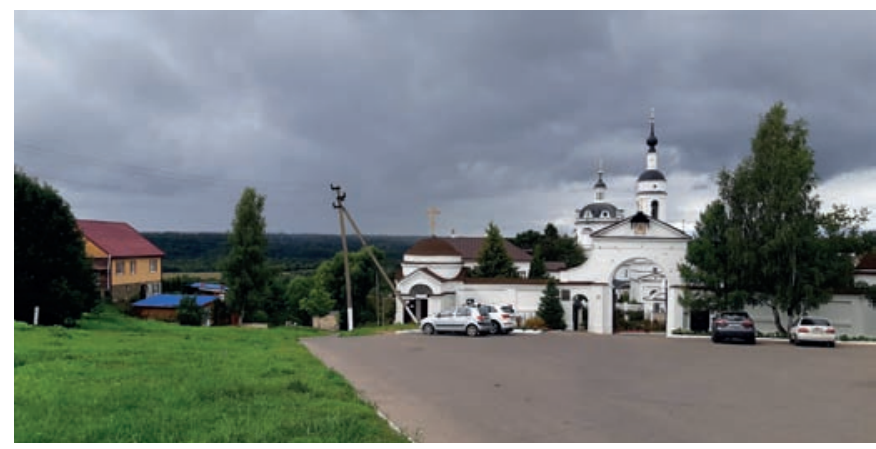

Pис. 2. Площадь перед Свято-Никольским Черноостровским монастырём. Малоярославец Калужской области. Фото Э.А. Шевченко. 2019 год

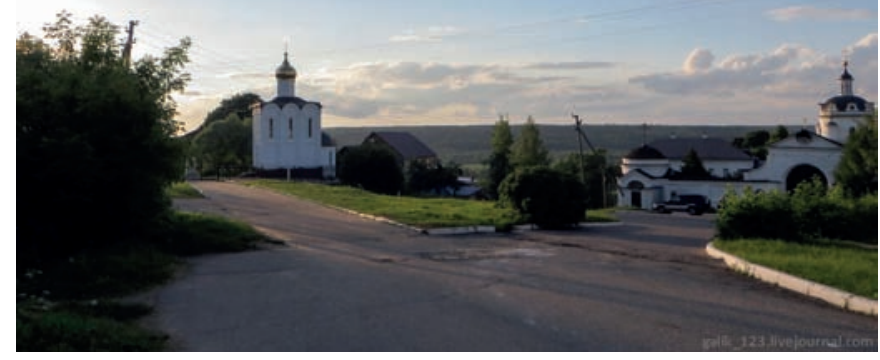

Рис. 3. Верхняя точка площади перед Свято-Никольским Черноостровским монастырём, с которой открывается панорама на долину реки Лужа. Город Малоярославец Калужской области (фото из открытых источников сети Интернет)
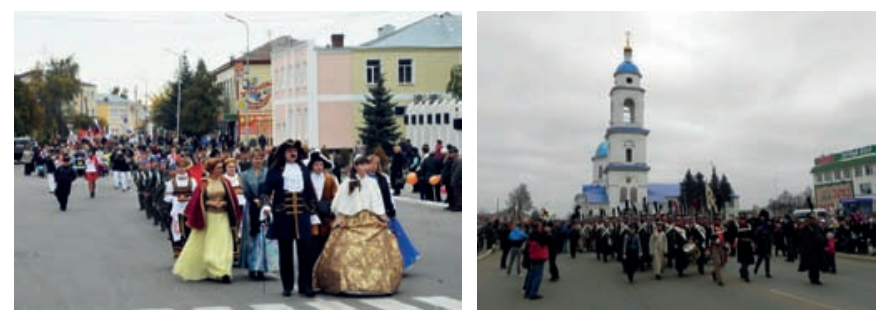

Рис. 4. Улицы Малоярославца в праздничный день ющая ОКН и усиливающая эмоциональное воздействие при восприятии объекта.

При перечислении градоформирующих качеств авторы Методических указаний 1988 года интуитивно предложили в качестве важных качеств нематериальные показатели:

- «памятные места, имеющие историко-мемориальную ценность и достоверность», в основе чего заложена память о некогда произошедшем знаковом для истории о событии, подтверждённая документальными источниками. Эти общественно значимые события, обряды, праздники, признанные городским сообществом, должны быть описаны и зафиксированы в фиксационном документе. Таким документом может быть паспорт нематериального культурного наследия, форма которого должна быть принята и утверждена на федеральном уровне;

- «эмоциональное воздействие» объекта при его визуальном восприятии, в основе показателя - чувство.

Необходимо включить в состав историко-культурной экспертизы исследование объектов нематериального культурного наследия (с предшествующей разработкой методики исследования).

То есть механизмом воздействия могут быть объекты, городское пространство, соотношения объектов в пространстве и многое другое. Одним из механизмов эмоционального воздействия могут быть памятные события, поддержанные знанием о них. Именно эмоциональность «места» является основным свойством «духа места» - места, где, по образному выражению Кристофера Дэйя, «...архитектура, хотя и возникающая из мёртвого материала, отнюдь не обязательно должна быть мертва: она может быть исполненной жизни. Создающие её элементы и связи между ними могут “петь" и людское сердце может звучать в резонанс этой мелодии» $[5$, с. 6].

То есть можно сказать, что «Дух места» и есть нематериальное наследие конкретного Места, которым может быть поселение или некая территория.

\section{Лuтература}

1. «Предмет охраны- это мина замедленного действия, заложенная под памятники»: интервью доктора искусствоведения Андрея Баталова [Электронный ресурс] // ИA REGNUM. - Режим доступа: http://www.regnum.ru/news/720826.html (дата обращения 10.05.2021).

2. Джейкоб. С. Архитектура как воссоздание / Сэм Джейкоб. - М. : «Strelka Press», 2012.

3. Славина Т.А. Предмет охраны. К вопросу об охране и использовании природно-культурного наследия / Т.А. Славина // Памятники истории и культуры Санкт-Петербурга. Исследования и материалы. Вып. 4. - СПб : КГИоП, 1997. - С. 10-32.

4. Анциферов, Н.П. Душа Петербурга : сборник / Н.П. Анциферов. - СПб : Рипол Классик, 2014.

5. Дэй, К. «Места, где обитает душа: архитектура и среда как лечебное средство / К. Дэй; Пер. с англ. В.Л. Глазычева. - М. : Ладья, $2000-280$ с. 
6. Каулен, М.E. Музеефикация историко-культурного наследия России / Каулен, М.Е. - М. : Этерна, 2012. - 432 с.

7. Курьянова, T.С. Сохранение нематериального культурного наследия: опыт национальных республик южной Сибири / Т.С. Курьянова // Вестник Томского государственного университета. - 2015. - № 391. - С. 113-117.

8. Мастеница, E.Н. Нематериальное наследие как объект музеефикации: теоретико-методологические основания / Е.Н. Мастеница // «Культура в евразийском пространстве: традиции и новации». - 2017. - № 1 (1). - С. 79-83. ISSN 2541- 772X

9. Уникальные территории в культурном и природном наследии регионов : Сб. науч. трудов. - М. : РНИИ культурного иприродного наследия, 1994. - 216 с.

10. Лефевр А. Производство пространства / А. Лефевр; Пер. с фр. - M. : Strelka Press, 2015. - 432 с.

11. Вопросы теории архитектуры. Образ мира в архитектуре : Сб. науч. Трудов / Под ред. И.А.Азизян - М. : НИИТИАГ, 1995. НИИТАГ.

\section{References}

1. «Predmet okhrany - eto mina zamedlennogo deistviya, zalozhennaya pod pamyatniki»: interv'yu doktora iskusstvovedeniya Andreya Batalova ["The subject of protection is a time bomb planted under the monuments": an interview with Andrey Batalov, a doctor of art history]. IA REGNUM. Access mode: http://www.regnum.ru/news/720826.html (Accessed 10.05.2021).

2. Dzheikob S. Arkhitektura kak vossozdanie [Architecture as a recreation]. Moscow, Strelka Press Publ., 2012.

3. Slavina T.A. Predmet okhrany. K voprosu ob okhrane $i$ ispol'zovanii prirodno-kul'turnogo naslediya [The subject of protection. On the issue of the protection and use of natural and cultural heritage]. In: Pamyatniki istorii i kul'tury SanktPeterburga. Issledovaniya i materialy [The subject of protection. On the issue of the protection and use of natural and cultural heritage]. The subject of protection. On the issue of the protection and use of natural and cultural heritage. Iss. 4. St. Petersburg, 1997, pp. 10-23.

4. Antsiferov N.P. Dusha Peterburga : sbornik [Soul of Petersburg. Collection]. St. Petersburg, Ripol Klassik Publ., 2014.

5. Dei K. Mesta, gde obitaet dusha: arkhitektura i sreda kak lechebnoe sredstvo [Places where the soul dwells: architecture and environment as a remedy] trans.from Engl. V.L. Glazychev. Moscow, Lad'ya Publ., 2000, 280 p.

6. Kaulen M.E. Muzeefikatsiya istoriko-kul'turnogo naslediya Rossii [Museumification of the historical and cultural heritage of Russia]. Moscow, Eterna Publ. , 2012, 432 p.. (In Russ.)

7. Kur'yanova T.S. Sokhranenie nematerial'nogo kul'turnogo naslediya: opyt natsional'nykh respublik yuzhnoi Sibiri [Preservation of Intangible Cultural Heritage: Experience of the National Republics of Southern Siberia] In: Vestnik Tomskogo gosudarstvennogo universiteta [Bulletin of Tomsk State University], 2015, no. 391, pp. 113-117. (In Russ., abstr.in Engl.)

8. Mastenitsa E.N. Nematerial'noe nasledie kak ob"ekt muzeefikatsii: teoretiko-metodologicheskie osnovaniya [Intangible heritage as an object of museification: theoretical and methodological foundations]. In: Kul'tura v evraziiskom prostranstve: traditsii i novatsii [Culture in the Eurasian space: traditions and innovations], 2017, no. 1 (1), pp. 79-83. ISSN 2541- $772 X$ (In Russ.)

9. Unikal'nye territorii $\vee$ kul'turnom i prirodnom nasledii regionov. Sb. nauch. trudov [Unique territories in the cultural and natural heritage of the regions. Collection of scientific works]. Moscow, Russian Research Institute of Cultural and Natural Heritage Publ.,1994, 216 p. (In Russ.)

10. Lefevr A. Proizvodstvo prostranstva [Production of space], trans.from French. Moscow, Strelka Press Publ., 2015, 432 p. (In Russ.)

11. Azizyan I.A. (ed.). Voprosy teorii arkhitektury. Obraz mira $v$ arkhitekture : Sb. nauch. Trudov [Questions of the theory of architecture. The image of the world in architecture. Collection of scientific works]. Moscow, NIITAG Publ.,1995. (In Russ

Шевченко Элеонора Арсеновна (Москва). Кандидат архитектуры, советник РААСН. Доцент кафедры «Градостроительство» ФГБОУ В0 «Национальный исследовательский Московский государственный строительный университет» (129337, Москва, Ярославское шоссе, д. 26. НИУ МГСУ). Эл.почта: shegal1948@mail.ru.

Shevchenko Eleonora A. (Moscow). Candidate of Architecture, Adviser of RAACS. Associate Professor of the Urban Planning Department at the National Research Moscow State University of Civil Engineering (26 Yaroslavskoye Highway, Moscow, 129337. NIU MGSU).E-mail: shegal1948@mail.ru. 